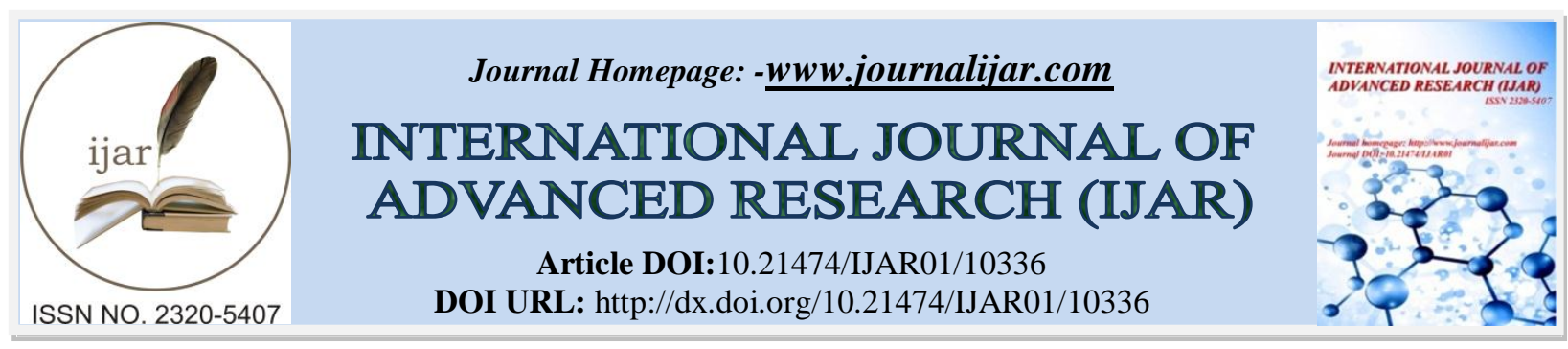

RESEARCH ARTICLE

\title{
INFLUENCE OF CORPORATE GOVERNANCE IN CORPORATE SOCIAL RESPONSIBILITIES RELATION WITH FIRM VALUE
}

\author{
Danypatra Sallata, Gagaring Pagalung and Ratna A. Damayanti \\ Hasanuddin University.
}

\section{Manuscript Info \\ Manuscript History \\ Received: 27 November 2019 \\ Final Accepted: 30 December 2019 \\ Published: January 2020 \\ Key words:- \\ Corporate Social Responsibility, \\ Corporate Governance, Firm Value}

\begin{abstract}
This study aims to examine influence of corporate social responsibility to firm value, influence of corporate governance to firm value, and influence of corporate governance to corporate social responsibility relationship with firm value. This study was conducted at the Indonesian Stock Exchange by using secondary data. Sampling was conducted by using purposive sampling from mining industry from 2009-2011. This research was an empirical study which used pooling data and using pooled least squre methode (PLS).The result of this research by using multivariate linear regression analysis show that corporate social responsibility have positive influence to firm value, while corporate governance failed to influence firm value, at the same time corporate governance as the moderating variable involve in this research managed to be a moderating variable but become a negative influence.
\end{abstract}

Copy Right, IJAR, 2020,. All rights reserved.

\section{Introduction:-}

The topic of corporate social responsibility has been widely discussed in the past decade and has received widespread attention from the government, business people, and the mass media in the country. According to Lako (2010), one of the reasons that encouraged the parties to give broad attention to the issue of corporate social responsibility is the increasingly widespread negative impacts of the social crisis (poverty and unemployment) and environmental crisis (natural disasters and global warming) in recent years. This makes the campaign about the idea of sustainable development (sustainable development) and sustainable corporation (sustainable corporation) increasingly promoted.

In Indonesia itself, the issue of corporate social responsibility is increasingly becoming a concern after on July 20 , 2007 the House of Representatives of the Republic of Indonesia (DPR RI) passed Law No.40 of 2007 concerning Limited Liability Companies (PT Law), one of which requires the company to implement corporate social responsibility and disclose information in the company's annual report. These obligations are contained in articles 66 and 74. This has increased the number of companies that disclose information about corporate social responsibility. Positive, negative or neutral relationships emerge from a variety of studies that have been conducted recently. Crisostimo et al. (2011) found that a neutral relationship emerged between corporate social responsibility and financial accounting performance. In line with the results of this study, Mc.Williams and Siegel (2001) in America revealed that corporate social responsibility will depend on company size, research and development, consumer income, labor market conditions, and the level in the industrial life cycle. The results found that when the model was specified, it was found that corporate social responsibility has a neutral impact on financial performance. 
In contrast to the results of previous studies, Cochran and Wood (1984) found that in the industry groups they examined, financial variables that were strongly correlated with corporate social responsibility were asset ages. Specifically illustrated that companies that have an older asset life, have a lower corporate social responsibility rating. In line with the research of Cochran and Wood (1984), using Fortune magazine's rating, McGuire et al. (1988) revealed that stock-market returns and measurements based on accounting are more related to corporate social responsibility than subsequent performance. The results also show that risk measurement has more association with corporate social responsibility. Several other studies such as Parquet and Eilbert (1975), Waddock and Graves (1997), Schuler and Cording (2006), Nuzula and Kato (2010), also showed positive results.

Several other studies, such as Fiori et.al (2007) who conducted research on companies listing in Italy for 6 periods (2002-2007). Fiori (2007) measures the relationship of corporate social responsibility and company stock prices. As a result, the relationship between corporate social responsibility disclosure that involves employees is positively related to stock prices, while disclosure of corporate social responsibility related to the community is negatively related to stock prices.

Friedman (1970) in his research though found that clients and employees were the main stakeholders, found that corporate social responsibility was not able to increase the value of the company. Vance (1975), which shows that disclosure of corporate social responsibility has a negative relationship with stock prices. Conelly and Limpaphayom (2003), Aupperle and Van Pham (1989) also get negative results between environmental disclosure and financial performance. Research by Nurlela and Islahuddin (2008) states that corporate social responsibility activities are not one of the factors that influence company value. Based on the description of previous research as described previously, it can be concluded that research on the relationship of corporate social responsibility and company performance has been done a lot but shows inconsistent results. This happens because there are still other factors that might affect the relationship between corporate social responsibility and corporate value.

The inconsistency of the results of previous studies led to the idea to include contingency variables that are expected to further strengthen (moderate) the relationship between corporate social responsibility and corporate value. In line with this, Arlow and Gannon (1982) in their research suggested the need for contingency variables.

\section{Materials And Methods:-}

Location and Research Design:

The location of the study was conducted at the Indonesia Stock Exchange (Makassar's Capital Market Information Center) using secondary data from 2009 to 2011.

\section{Population and Sample:}

The population in this study are companies engaged in mining. The sample selection is done by purposive sampling method. There were 32 companies that were eligible to be used as samples in this study.

\section{Method Of Collecting Data:-}

This study uses secondary data sources, namely as an interpretation of primary data (Cooper and Schindler, 2006). In other words, the data obtained by researchers indirectly through intermediary media (obtained and recorded by other parties) in the form of sustainability reports, annual reports (annual reports), and financial statements of the company. The three reports were obtained online through the Indonesia Stock Exchange's website (www.idx.co.id), the company's official website, and the Indonesian Capital Market Directory (ICMD) from 2009 to 2011.

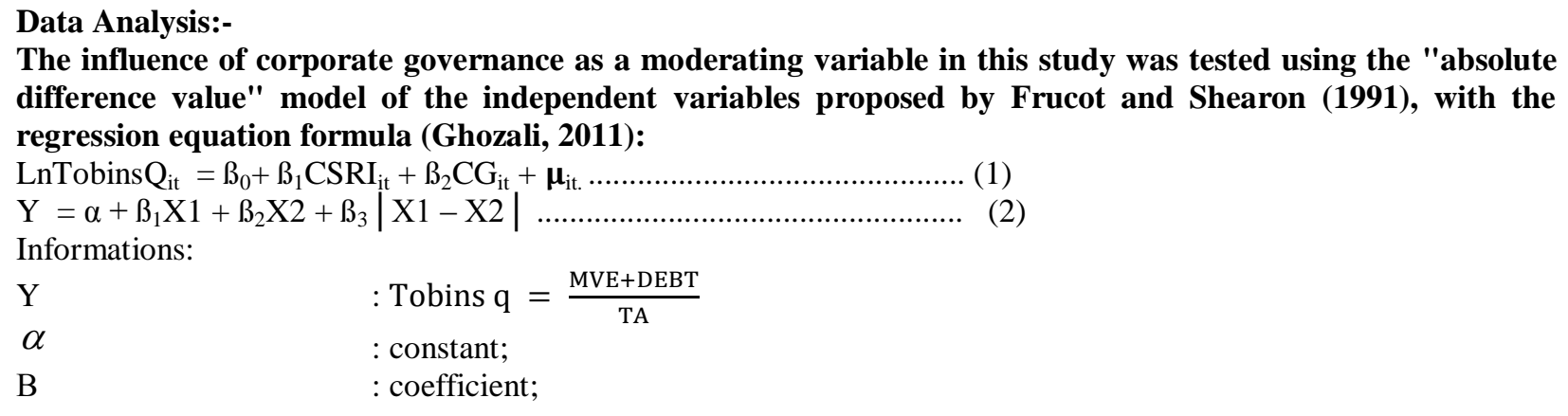


$\mathrm{X} 1$

$\mathrm{X} 2$

$\mathrm{Xi}$

$\mathrm{X} 1-\mathrm{X} 2$
: Corporate Social Responsibilty (CSRI)

: Corporate Governance (CG)

: standardized score $[\mathrm{Xi}-\overline{\mathrm{X}} \mathrm{i} / \sigma \mathrm{Xi}]=\mathrm{Zscore}$

: interactions measured by the absolute value of the difference between $\mathrm{X} 1$ and $\mathrm{X} 2$.

\section{Results:-}

\section{Classic Assumption Test:}

The Kolmogorov-Smirnov (KS) test results on the residual value of the model after the transformation showed that the residuals were normally distributed, because all three variables had insignificant Kolmogorov-Smirnov $Z$ values, as shown by each Kolmogorov-Smirnov Z value was CSRI of 0.617 (sig 0.840), CG of 1.110 (sig. 0.170), and TobinsQ of 0.463 (sig. 0.983). The results of testing multicollinearity assumptions indicate that the regression equation has passed the test of these assumptions, namely the absence of multicollinearity between independent variables. This can be seen from the Tolerance value that is not below 0.10 and the VIF value is not above 10 The Glejser test results in Table 10 above show that the two independent variables are not significant. This means that the research model is stated to pass the assumption of homoscedasticity or there is no violation of the assumption of heteroscedasticity.

\section{Hypothesis Testing:}

Hypothesis 1 test results provide information that the value of the slope coefficient given by CSRI of 1.65 with a tstatistic value of 2.35 is significant at the $\alpha=5 \%$ level, so the H1 hypothesis stating that CSR has a positive effect on firm value is acceptable. This means that the increase in the value of the company proxied by Tobins' $\mathrm{Q}$ will be in line with the increase in CSRI as a corporate social responsibility. Hypothesis 2 test results show that Corporate Governance provides a slope coefficient of 0.125 with a t-statistic value of 0.902 which is not significant at the $\alpha=$ $5 \%$ level. So the $\mathrm{H} 2$ hypothesis which states that Corporate Governance has a positive effect on company value cannot be accepted or rejected. The results of the AbsCSRI_CG moderating variable turned out to give a significant slope coefficient of -0.382 , ie with a significance probability of 0.024 which is below 0.05 . These findings indicate that the CG variable can be a moderating variable that is a negative interaction (negative interaction) relationship between CSRI and Tobin's Q.

\section{Discussion:-}

The company's value in the findings of this study indicates the reaction of investors to the perception of achievement of corporate social responsibility as revealed in the annual annual report. Sujoko and Soebiantoro (2007) company achievements are often associated with stock prices. So that the increasing share prices in the market, will have consequences on increasing the value of the company, and shape market confidence in the company's current and future prospects. The increase in CSR or corporate social responsibility in this study has a positive impact on the value of mining companies (samples) that can convince the market, especially investors, for the long-term sustainability of the company.

CG as an independent variable, shows that $\mathrm{CG}$ gives an insignificant value which means CG does not affect the value of the company (Tobin's Q), so this study does not support the H2 hypothesis that CG has a positive effect on firm value. This indicates that, in the observation period of this study (2009-2011), the available CG data both related to managerial ownership, institutional ownership, the size of the board of commissioners, and the proportion of independent directors, did not support the hypothesis proposed in this study. This result does not support the view of Jensen and Meckling (1976), that increased managerial ownership can better align the interests of managers and shareholders, which can increase the value of the company.

The presence of the CG variable as a moderating relationship between CSR and Tobin's Q is meaningful. Significance of Results These findings indicate that the CG variable is a moderating variable that is a negative interaction (negative interaction) the relationship between CSR and company value, which means that for higher CG values, it has an impact on the relationship between CSR on more negative company values. So the H3 hypothesis which states that CG has a positive effect on the relationship of CSR with company value cannot be accepted or rejected, because the CG variable can be a moderating variable but is a negative interaction in this model. This result is different from Rustiarini's (2010) research findings on manufacturing companies on the Indonesia Stock Exchange, that CG has a positive effect on the relationship of CSR disclosure with firm value. 


\section{Conclusions And Recommendations:-}

The variable corporate social responsibility has a positive effect on the variable firm value so that the $\mathrm{H} 1$ of this study can be accepted. This is in line with the results of Bringham and Gapensi's research (1996) which states that the interests of the primary stakeholder group can be measured by the movement of the company's value on the stock exchange where the high value of the company is followed by high shareholder prosperity. While from an economic perspective, the company will disclose information if the information will increase the value of the company (Verecchia, 1983, in Sayekti and Wondabio, 2007).

Other independent variables, corporate governance failed to influence the value of the company so $\mathrm{H} \neg 2$ of this study was rejected. This study is not in line with the research of Jensen and Meckling (1976), which states that increasing managerial ownership can better align the interests of managers and shareholders, which can increase company value. The results of this study are in line with agency theory which reveals that there is a separation between owners and workers (agents) within the company (Jensen and Meckling, 1976). In other words, the disclosure of information presented by companies in the mining industry is still lacking, so the value of corporate governance in this study has no effect on company value.

The corporate governance variable as moderation involved in the research model turned out to be a moderating variable but it became a negative influence of the relationship between corporate social responsibility and company value so that the $\mathrm{H} 3$ research was rejected. This indicates the lack of implementation of corporate governance (proxy) will have a negative impact on the relationship of corporate social responsibility with corporate value. This study is in line with the research of Barnea and Rubin in Ammann et al. (2011) found a negative relationship between corporate social responsibility and corporate governance if corporate governance was measured using only managerial ownership. This research is only limited to the mining sector, so it gives results that cannot be generalized, so the following researchers are advised to make comparisons of several industrial sectors.

Future studies can examine more deeply the other variables that have a correlation and are expected to be able to strengthen the relationship between corporate social responsibilities to the value of the company because of this study found that corporate social responsibilities and corporate governance only give $11 \%$ influence on the value of the company.

Attachment:

\begin{tabular}{|c|c|c|c|c|}
\hline \multicolumn{5}{|l|}{ Normality Test } \\
\hline & & LnTobinsQ & X1 CSRI & REGR factor score 1 for analysis 1 \\
\hline \multicolumn{2}{|l|}{$\mathrm{N}$} & 32 & 32 & 32 \\
\hline \multirow[t]{2}{*}{ Normal Parameters ${ }^{\mathrm{a}, \mathrm{b}}$} & Mean & .5151 & .3321314 & .0000000 \\
\hline & Std. Deviation & .79743 & .19728490 & 1.00000000 \\
\hline \multirow[t]{3}{*}{ Most Extreme Differences } & Absolute & .082 & .109 & .196 \\
\hline & Positive & .079 & .109 & .196 \\
\hline & Negative & -.082 & -.071 & -.167 \\
\hline \multicolumn{2}{|l|}{ Kolmogorov-Smirnov Z } & .463 & .617 & 1.110 \\
\hline \multicolumn{2}{|l|}{ Asymp. Sig. (2-tailed) } & .983 & .840 & .170 \\
\hline \multicolumn{5}{|l|}{ a. Test distribution is Normal. } \\
\hline \multicolumn{5}{|l|}{ b. Calculated from data. } \\
\hline
\end{tabular}

\begin{tabular}{|l|l|l|l|}
\hline \multicolumn{2}{|l|}{ Multicollinearity Test } \\
\hline \multirow{2}{*}{ Model } & Collinearity Statistics \\
\cline { 3 - 4 } & X1 CSRI & .957 & VIF \\
\hline \multirow{2}{*}{1} & REGR factor score 1 for analysis 1 & .957 & 1.045 \\
\hline \multicolumn{2}{|l|}{ a. Dependent Variable: LnTobinsQ } & \multicolumn{2}{|l}{} \\
\hline
\end{tabular}

\begin{tabular}{|c|c|c|c|c|c|}
\hline \multicolumn{6}{|c|}{ Heteroscedasticity Test } \\
\hline \multirow[t]{2}{*}{ Model } & \multicolumn{2}{|c|}{ Unstandardized Coefficients } & Standardized Coefficients & \multirow[t]{2}{*}{$\mathrm{t}$} & \multirow[t]{2}{*}{ Sig. } \\
\hline & B & Std. Error & Beta & & \\
\hline \begin{tabular}{l|l}
1 & (Constant)
\end{tabular} & .524 & .136 & & 3.843 & .001 \\
\hline
\end{tabular}




\begin{tabular}{|c|c|c|c|c|c|}
\hline X1 CSRI & .269 & .356 & .140 & .755 & .456 \\
\hline REGR factor score 1 for analysis 1 & .065 & .070 & .172 & .923 & .364 \\
\hline
\end{tabular}

Results of regression models of the influence of CSRI and CG on Tobin's Q (secondary data processed with SPSS 17, 2012)

\begin{tabular}{|l|l|l|l|}
\hline LnTobins $_{\mathrm{it}}=\beta_{0}+\beta_{1} \mathrm{CSRI}_{\mathrm{it}}+\beta_{2} \mathrm{CG}_{\mathrm{it}}+\boldsymbol{\mu}_{\mathrm{it}}$ & Koefisien & t-statistik & Probability \\
\hline Variabel & $-0,032$ & $-0,121$ & 0,905 \\
\hline Intercept (constant) & 1.649 & $2.351^{*}$ & 0,026 \\
\hline $\mathrm{X} 1$ CSRI & 0,125 & 0,902 & 0,375 \\
\hline REGR factor score 1 for analysis 1 & \multicolumn{2}{l}{} \\
\hline Note: significant at the level $\alpha=* 5 \%$; Adjusted $\mathrm{R}^{2}=0.107 ;$ F-Value $=2,854 \quad$ (Sig. 0,07) \\
\hline
\end{tabular}

Moderate model regression results (secondary data processed with SPSS 17, 2012)

\begin{tabular}{|c|c|c|c|}
\hline$S \mathrm{I}_{\mathrm{it}}+\mathrm{I}_{2} \mathrm{ZC} \mathrm{G}_{\mathrm{it}}+\mathrm{I}_{3}$ & $\begin{array}{l}\text { AbsCSRI it- } \\
\text { Koefisien }\end{array}$ & t-statistik & Probability \\
\hline Intercept & 1,011 & $4,175^{*}$ & 0,000 \\
\hline Zscore: X1 CSRI & 0,383 & $2,930^{*}$ & 0,007 \\
\hline Zscore: REGR factor score 1 for analysis 1 & 0,218 & 1,625 & 0,115 \\
\hline AbsCSRI_CG & $-0,382$ & $-2,381^{*}$ & 0,024 \\
\hline
\end{tabular}

\section{Reference:-}

1. Ammann, M., Oesch, D., dan Schmid, M.M.. 2011. "Corporate Governance and Firm Value: International Evidence". Journal of Empirical Finance 18. (2001) 36-55.

2. Aupperle, K. E., and Pham, D. V.. 1989. "An expanded investigation into the relationship of corporate social responsibility and financial performance". Employee Responsibilities and Rights Journal, 2.4: 263-274.

3. Bringham, E.F. dan Gapenski, L.C., 1996. "Intermediate Finance Management (5 ${ }^{\text {th }}$ ed.)". Harbor Drive: The Dryden Press

4. Cooper D. R. \& Schindler P. S. (2006). Metode Riset Bisnis, Volume 1, Edisi 9. PT Media Global Edukasi.

5. Connelly, J.T., Limpaphayom, P., 2004. "Environmental Reporting and Firm Performance: Evidence from Thailand, Journal of Corporate Citizenship, Volume 13, p. 137-149

6. Cochran, P. L., dan Wood, R.A. 1984. "Corporate Social Responsibility and Financial Performance.” Academy of Management Journal, 27 (1): 42-56

7. Chrisostomo, L. V., Freire, F.D.S., Vasconcellos, F.C.D. 2011. "Corporate Social Responsibility, Firm Value and Financial Performance in Brazil. Social Responsibility Journal, Vol. 7 Iss: 2 pp. 295 - 309.

8. Fiori, G., Di Donato, F., dan Izzo, M. F. 2007. "Corporate Social Responsibility and Firm Performance. An Analysis on Italian Listed Companies”, http://ssrn.com/abstract=1032851 [diakses 25 Oktober 2012]

9. Friedman, M. 1970. "The Social Responsibility of Business is to Increase its Profits". New York. The New York Times Company.

10. Ghozali, I. 2012. "Aplikasi Analisis Multivariate dengan Program IBM SPSS Edisi 6". Semarang. Badan Penerbit Universitas Diponegoro

11. Jensen, M.C. dan W.H. Meckling. 1976. "Theory of the Firm: Managerial Behavior, Agency Costs and Ownership Structure". Journal of Financial Economics. Vol 3. No 4. Pp. 305-360.

12. Lako, A. 2011. "Dekonstruksi CSR \& Reformasi Paradigma Bisnis \& Akuntansi". Jakarta: Erlangga.

13. McGuire, Jean et al. 1988. Corporate Social Responsibility and Firm Financial Performance. Academy of Management Journal, 1988, Vol. 31. No.4, 854-872.

14. Mc.Williams, A. dan Siegel, D. 2001. "Corporate Social Responsibility: A Theory of The Firm Perspective". Academy of Management Review 2001, Vol. 26, No. 1, 117-127.

15. Nuzula, N. F. dan Kato, M. 2010. "Do Japanese Capitaxal Markets Respond to the Publication of Corporate Social Responsibility Reports". Journal of Accounting, Finance and Economics Vol. 1. No. 1. July 2011 Issue. Pp. 48-60. 
16. Rustiarini, N. W. 2010. "Pengaruh corporate governace pada hubungan corporate social responsibility dan nilai perusahaan." Simposium Nasional Akuntansi XIII, Purwokerto.

17. Parket, R. dan Eilbert, H. 1975. "The Social Responsibility: The Underlying Factors". Business Hoizon, 1975.

18. Schuler, A. D. dan Cording, M. 2006. "A Corporate Social Performance-Corporate Financial Performance Behavioral Model for Consumers". ACAD MANAGE REV July 1, 2006 vol. 31 no. 3 540-558.

19. Sujoko dan Soebiantoro, U. 2007. "Pengaruh Struktur Kepemilikan Saham, Leverage, Faktor Intern dan Faktor Ekstern Terhadap Nilai Perusahaan". Jurnal Ekonomi Manajemen, Fakultas Ekonomi, Universitas Petra.

20. Undang-Undang Republik Indonesia Nomor 40 Tahun 2007 Tentang Perseroan Terbatas. (Online), (Www.Bapepam.Go.Id/) diakses tanggal 30 Juli 2012 Jam 17.33 wita.

21. Waddock, A. S. dan Graves, B. S. 1997. "The Corporate Social Performance-Financial Performance Link". Strategic Management Journal Volume 18, Issue 4.

22. Vance, S. C. 1975. “Are socially responsible corporations good investment risks?”. Management Review, 64: 18-24. 